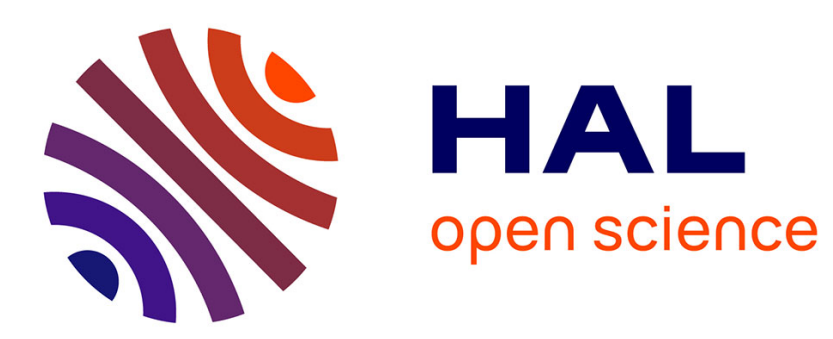

\title{
Hydration in silica based mesoporous materials: a DFT model
}

Maciej Gierada, Ivan Petit, Jaroslaw Handzlik, Frederik Tielens

\section{To cite this version:}

Maciej Gierada, Ivan Petit, Jaroslaw Handzlik, Frederik Tielens. Hydration in silica based mesoporous materials: a DFT model. Physical Chemistry Chemical Physics, 2016, 48, pp.32962-32972 10.1039/C6CP05460A . hal-01411472

\section{HAL Id: hal-01411472 \\ https://hal.sorbonne-universite.fr/hal-01411472}

Submitted on 7 Dec 2016

HAL is a multi-disciplinary open access archive for the deposit and dissemination of scientific research documents, whether they are published or not. The documents may come from teaching and research institutions in France or abroad, or from public or private research centers.
L'archive ouverte pluridisciplinaire HAL, est destinée au dépôt et à la diffusion de documents scientifiques de niveau recherche, publiés ou non, émanant des établissements d'enseignement et de recherche français ou étrangers, des laboratoires publics ou privés. 


\title{
Hydration in Silica Based Mesoporous Materials; A DFT
}

\section{Model}

\author{
Maciej Gierada ${ }^{a,{ }^{*}}$ Ivan Petit ${ }^{b}$, Jarosław Handzlik ${ }^{a}$, Frederik, Tielens ${ }^{b, *}$
}

${ }^{a}$ Faculty of Chemical Engineering and Technology, Cracow University of Technology, ul. Warszawska 24, 31-155 Kraków, Poland

${ }^{\mathrm{b}}$ Sorbonne Universités, UPMC Univ Paris 06, UMR 7574, Laboratoire Chimie de la Matière Condensée, Collège de France, 4 place Jussieu, 75252 Paris Cedex 05, France

\section{AUTHOR INFORMATION}

\section{Corresponding Author:}

e-mail address: frederik.tielens@upmc.fr

e-mail address:mgierada@chemia.pk.edu.pl 


\begin{abstract}
MCM-41 material is very commonly used as a support for catalysts. However, theoretical investigations are significantly limited due to the lack of appropriate models that well and accurately describe the real material and enable effective computation at the same time. In this work, our aim is to obtain calculable models at the DFT level of MCM-41 which are as close as possible to the real material. In particular the hydration degree has been investigated, and we present and characterize here for the first time a model for the MCM-41 unit cell filled with explicit solvent water molecules. This is particularly important, because the models developed here are aimed to be further applied in theoretical ab initio/DFT studies of adsorption or as a support for modelling active sites in catalysts.
\end{abstract}

KEYWORDS: Silica; MCM-41; DFT; Hydration 


\section{INTRODUCTION}

Silicon dioxide or silica is the most common mineral on Earth. Its application is therefore very attractive and stimulated in many applications, beside its use in construction materials such as cement and glass, it is important in catalysis in which it is used as a support and in chromatography, electronic devices, but also in food, pharmaceutical applications and in biomineralization. ${ }^{1}$ Different reviews summarize its chemical properties. ${ }^{2-4}$ An important feature of silica is the existence of a large variety of polymorphs composed of $\mathrm{SiO}_{4}$ tetrahedra. The high flexibility of the Si-O-Si bond, with a bending energy barrier about $4 \mathrm{~kJ} / \mathrm{mol}^{5}$ is responsible for the great number of existing polymorphs, either natural or synthetic: several crystalline forms such as quartz, cristobalite, tridymite, diatomite, and edingtonite, noncrystalline glasses or sol-gel phases, and micro/mesoporous materials. In this study we focus on the amorphous polymorphs, which alike other amorphous materials are a challenge for modeling.

The silica surface shows undercoordinated atoms, such as three coordinated Si atoms, terminal oxygens, and strained Si-O-Si bridges in small size 2 and 3-membered rings. These silica defects react with water in ambient conditions to form surface hydroxyl groups called silanols ${ }^{3,6,7}$ which can make the surface hydrophilic. In contrast, a non-defective clean $\mathrm{SiO}_{2}$ surface is hydrophobic. ${ }^{8-11}$

Due to the amorphous nature of silica, the classical diffraction techniques cannot be used to give structural information. Yet its surface exhibits a rich diversity of chemical groups.

There are different types of silanols that exist on top of silica surface which are schematically presented in the Figure 1. The first general distinction is between the single and geminal silanols. Single silanols are bound to a $\mathrm{Si}$ atom involved in three $\mathrm{Si}-\mathrm{O}-\mathrm{Si}$ siloxane groups, whereas geminal silanols complete the coordination sphere of a Si atom involved in two siloxane groups. Silanols can be also associated with $\mathrm{H}-$ bond interaction with other silanols or siloxane bridges. Although many authors ${ }^{9,10,12-14}$ discriminate vicinal silanols as one of the existing types of $\mathrm{SiOH}$ groups, their exact definition is sometimes different in different papers ${ }^{9,12}$ and spectroscopic characterization is rather poorly established. Because of that, we are not distinguishing and discussing vicinal silanols in this paper. We treat vicinal silanols as single, since they have one -OH group attached to $\mathrm{Si}$ atom, in contrast to geminal silanols (Fig. 1).

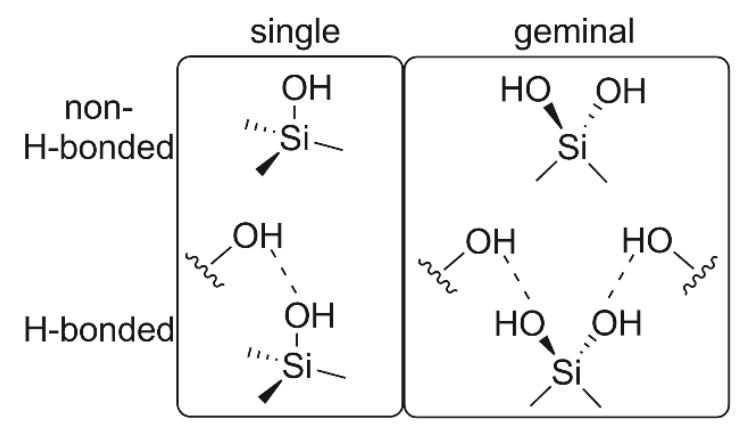

Figure 1. Types of silanol groups existing on the surface of silica 
The most important chemical functions of amorphous silica, surface silanols on the surface, have been characterized mainly by means of vibrational spectroscopies and NMR: IR ${ }^{15,16}$, Raman ${ }^{17,18}$ and ${ }^{29}$ Si MAS, CP-MAS ${ }^{9,19-22}$ and ${ }^{1} \mathrm{H} \mathrm{MAS}^{23-30} \mathrm{NMR}$.

The silanol SiO-H stretching frequencies of $\mathrm{H}$-bonded silanols are observed around $3550 \mathrm{~cm}^{-1}$, while isolated silanols vibrate between $3747-3750 \mathrm{~cm}^{-1} .2,3,15$ Theoretical studies have complemented the lack of information using different approaches. First, force field calculations have allowed to propose large size models (several thousands of atoms) of amorphous silicas, which have been validated with experimental data such as Si-O-Si angles, Si-O bond lengths, and ring size distributions. ${ }^{31-41}$ The bulk, surfaces, and their reactivity toward water to generate a hydroxylated surface have also been studied. ${ }^{14,31,32,42-50}$ Second, ab initio calculations combined or not with classical MD (molecular dynamics) to understand adsorption sites and the chemical reactivity of the anhydrous surface ${ }^{14,44}$ and hydroxylated amorphous silica ${ }^{14,49}$ have been performed as well.

An interesting example of amorphous silica are the mesoporous ordered materials, such as MCM-41. ${ }^{51-53}$ This material is described by a hexagonal array of roughly cylindrical, straight, unconnected pores which diameter can be engineered. Mesoporous structures usually have a high surface area, as well as a high pore volume, which make them very attractive as catalytic supports. MCM-41 can also be used to adsorb different molecules, including biomolecules, in confined spaces. ${ }^{54}$ Nowadays, this material is very commonly used as a support for nano-objects. However, theoretical investigations are significantly limited due to the lack of appropriate models that well and accurately describe the real material and enable effective computation at the same time.

In this work, our aim is to obtain calculable models of MCM-41 which are as close as possible to the real material. This is particularly important, since we aim to use the developed models here to be further applied in theoretical studies of adsorption or as a support for modelling active sites in catalysts. In 2008 one of us presented, characterized and verified a full DFT amorphous hydroxylated silica model, ${ }^{55}$ which was recently successfully employed in computational studies of $\mathrm{Cr},{ }^{56-58} \mathrm{Mo},{ }^{59} \mathrm{~W},{ }^{60} \mathrm{~V},{ }^{61} \mathrm{Nb}^{62}$ and $\mathrm{Au}^{63,64}$ oxide centers on $\mathrm{SiO}_{2}$. Other examples of applications were also investigated in the field of adsorption of bioorganic molecules, ${ }^{65-67}$ surfactants, ${ }^{68}$ and ionic liquids. ${ }^{69,70}$ Here, we are using this previously developed silica slab ${ }^{55}$ to prepare mesoporous structures. Although some models of MCM-41 material were postulated in the literature so far, all of them, beside one, are limited to molecular mechanics and kinetic Monte Carlo techniques. $^{71-74}$ Only Ugliengo et al. ${ }^{75,76}$ studied MCM-41 at DFT level (B3LYP), however, the model developed by the authors is characterized by the high silanol density $\left(7.2 \mathrm{OH} \mathrm{nm}^{-2}\right)$, which seems to be too high to account for adequate representation of the real MCM-41 surface. That model has been recently redefined including dispersion interactions and used in the static ${ }^{77,78}$ and $\mathrm{AIMD}^{78}$ studies of drug molecules 
adsorption in confined spaces, however, the silanol density remain unchanged. One should note that small cluster models of mesoporous material studied at B3LYP level were also published, ${ }^{79}$ but they are far from being realistic.

In this work, six realistic models of MCM-41 mesoporous material, characterized by different degrees of hydroxylation, expressed as a function of their silanol density, are reported. More specifically, models with the 5.8, 5.8 with $\mathrm{H}_{2} \mathrm{O}$ inside the pores, 4.8, 3.6, 2.3 and $1.7 \mathrm{OH} \mathrm{nm}{ }^{-2}$ (models $\mathbf{A}, \mathbf{B}, \mathbf{C}, \mathbf{D}, \mathbf{E}$ and $\mathbf{F}$, respectively) are studied. Those models describe MCM-41 surface at different temperatures and/or water vapor pressures. It is worth to emphasize here that such a comprehensive and extensive DFT study on modeling of MCM-41 structure have never been done before.

\section{COMPUTATIONAL DETAILS}

The geometry optimization was performed using Pardew-Burke-Ernzerhof (PBE) functional ${ }^{80}$ implemented in Vienna $\mathrm{Ab}$ Initio Simulation Package (VASP). ${ }^{81-83}$ This functional was previously successfully used to model amorphous silica structure. ${ }^{55}$ The electron-ion interaction was described by the projector augmented-wave (PAW) method. ${ }^{84,85}$ Standard PAW atomic parameters were used with a cutoff energy of $400 \mathrm{eV}$. To account for dispersion interactions, single point energy calculation were performed at PBE-D3(BJ) level. ${ }^{86,87}$ To determine harmonic vibrational frequencies, Hessian matrix was calculated by the finite difference method, i.e., each relaxed ion was displaced in the direction of each Cartesian coordinate and the Hessian was determined from the forces. Taking the limited computational power into account, as well as the size of our models, only silanols, i.e., Si-OH groups, was considered in the Hessian matrix. For the graphic presentation of the models developed, Materials Studio 5.5 software was applied. ${ }^{88}$ To obtain model B, where water molecules are inside the pores, Packmol package ${ }^{89,90}$ was used. Packing procedure were done with the initial water-water and water-MCM-41 distance of 2 and $3 \AA$, respectively. In some cases, several $\mathrm{H}_{2} \mathrm{O}$ molecules had to be displaced manually, in order to obtain optimizable geometry of the whole system. Then, a full relaxation of such model were performed with the fixed unit cell parameters.

The dehydroxylation energy $\Delta E_{d e h}\left(\mathrm{~T}_{0}\right)$ of removing water molecules from the high hydroxylated surface to obtain models with lower silanol density was calculated adopting the following equation (1):

$$
\Delta E_{d e h}\left(T_{0}\right)=E_{i}\left(T_{0}\right)+n E_{\text {water }}\left(T_{0}\right)-E_{A}\left(T_{0}\right)
$$

where $E_{i}\left(\mathrm{~T}_{0}\right)$ and $E_{A}\left(\mathrm{~T}_{0}\right)$ are the PBE-D3(BJ) energies at $\mathrm{T}=0 \mathrm{~K}$ of partially dehydroxylated $(\mathbf{C}-\mathbf{F})$ and high hydroxylated (A) models, respectively, $\mathrm{n}$ is a number of water molecules removed in considered 
dehydroxylation step and $E_{\mathrm{water}}\left(T_{0}\right)$ is the PBE-D3(BJ) energy at $\mathrm{T}=0 \mathrm{~K}$ of an isolated water molecule calculated using the same unit cell dimensions as in the case of MCM-41 models.

To account for temperature and water partial pressure dependence, the Gibbs energies $\Delta G_{d e h}(\mathrm{~T}, \mathrm{p})$ were estimated assuming that differences between the Gibbs energies for condensed phases are equal to the differences in their calculated electronic energies and only contributions to enthalpy and entropy of gas water molecule are included (equation 2), following the procedure described by Digne et al. ${ }^{91}$ :

$$
\Delta \mathrm{G}_{\mathrm{deh}}\left(\mathrm{T}, \mathrm{p}_{\mathrm{H} 2 \mathrm{O}}\right)=\Delta \mathrm{E}_{\mathrm{deh}}\left(\mathrm{T}_{0}\right)+\mathrm{n}\left[\Delta \mathrm{g}_{\mathrm{water}}\left(\mathrm{T}, \mathrm{p}_{0}\right)+\mathrm{RT} \ln \left(\frac{\mathrm{p}_{\mathrm{H} 2 \mathrm{O}}}{\mathrm{p}_{0}}\right)\right]
$$

where $\mathrm{p}_{0}=1 \mathrm{~atm}, \mathrm{~T}_{0}=0 \mathrm{~K}, \mathrm{R}-$ gas constant and $\Delta \mathrm{g}_{\mathrm{deh}}\left(\mathrm{T}, \mathrm{p}_{0}\right)$ is the Gibbs energy correction for $\mathrm{H}_{2} \mathrm{O}$ molecule calculated from statistical thermodynamics using PBE functional ${ }^{80}$ combined with def2QZVPPD basis set ${ }^{92}$ implemented in Gaussian 09 set of programs. ${ }^{93}$

AIMD simulations were also carried out with the package CP2K/Quickstep, ${ }^{94}$ consisting in BornOppenheimer MD (BOMD) PBE electronic representation including Grimme (D3) correction for dispersion, ${ }^{86}$ GTH pseudopotentials, ${ }^{95,96}$ a combined Plane-Wave (300 Ry density cutoff) and TZVP basis sets. The BOMD are performed using the NVT ensemble. The Nosé-Hoover thermostat is used to control the average temperature at $300 \mathrm{~K}$. Trajectories are accumulated 8 ps (whom 3 ps of equilibration) with a time step of $0.5 \mathrm{fs}$.

\section{RESULTS AND DISCUSSION}

$\underline{\text { The structural properties }}$

Table 1. Properties of the models of MCM-41 material

\begin{tabular}{|c|c|c|c|c|}
\hline \multirow[b]{2}{*}{ property } & \multicolumn{3}{|c|}{ Model } & \multirow[t]{2}{*}{ Exp. } \\
\hline & $\mathbf{A}$ & $\mathbf{B}$ & $\mathbf{F}$ & \\
\hline \multirow[t]{3}{*}{ unit cell parameters $(\AA)$} & $a=36.29$ & $a=36.29$ & $a=36.29$ & \\
\hline & $b=36.96$ & $b=36.96$ & $b=36.96$ & \\
\hline & $c=11.60$ & $c=11.60$ & $c=11.60$ & \\
\hline \multirow[t]{3}{*}{ angles $\left({ }^{\circ}\right)$} & $\alpha=90.46$ & $\alpha=90.46$ & $\alpha=90.46$ & \\
\hline & $\beta=91.60$ & $\beta=91.60$ & $\beta=91.60$ & \\
\hline & $\gamma=61,36$ & $\gamma=61,36$ & $\gamma=61,36$ & \\
\hline pore diameter $(\AA)$ & $27-32$ & $27-32$ & $28-33$ & $25-40^{b}$ \\
\hline wall thickness $(\AA)$ & $6-8$ & $6-8$ & $5-8$ & $7-30^{c}$ \\
\hline \multirow[t]{2}{*}{ wall density $\left(\mathrm{g} \mathrm{cm}^{-3}\right)$} & 2.8 & 2.8 & 2.5 & $2.7-3.0^{\mathrm{d}}$ \\
\hline & & & & $2.15^{\mathrm{e}}$ \\
\hline
\end{tabular}




\begin{tabular}{|c|c|c|c|}
\hline T-site density $\left(T\right.$-site $\left.\mathrm{nm}^{-3}\right)$ & 8.6 & 8.6 & 8.6 \\
\hline $\begin{array}{l}\text { T-site density of the wall } \\
\left(\mathrm{T} \text {-site } \mathrm{nm}^{-3}\right)\end{array}$ & 25.4 & 25.4 & 24.1 \\
\hline \multirow[t]{3}{*}{ molecular formula } & $\mathrm{Si}_{117} \mathrm{O}_{269} \mathrm{H}_{70}$ & $\mathrm{Si}_{117} \mathrm{O}_{482} \mathrm{H}_{496}$ & $\mathrm{Si}_{117} \mathrm{O}_{244} \mathrm{H}_{20}$ \\
\hline & $117 \mathrm{SiO}_{2} \cdot 35 \mathrm{H}_{2} \mathrm{O}$ & $117 \mathrm{SiO}_{2} \cdot 35 \mathrm{H}_{2} \mathrm{O}$ & $117 \mathrm{SiO}_{2} \cdot 10 \mathrm{H}_{2} \mathrm{O}$ \\
\hline & & $+213 \mathrm{H}_{2} \mathrm{O}$ & \\
\hline mass of unit cell $\left(\mathrm{g} \mathrm{mol}^{-1}\right)$ & 7660 & 11498 & 7210 \\
\hline silanols density $\left(\mathrm{OH} \mathrm{nm}{ }^{-2}\right)$ & 5.8 & 5.8 & 1.7 \\
\hline number of silanols & 70 & 70 & 20 \\
\hline single & 62 & 62 & 20 \\
\hline geminal & 8 & 8 & 0 \\
\hline silanols involved in $\mathrm{H}$-bond ${ }^{a}$ & 40 & 67 & 7 \\
\hline
\end{tabular}

${ }^{\mathrm{a}}$ H-bond cutoff (O-H distance): $2.20 \AA \AA ;{ }^{\mathrm{b}} \operatorname{Ref} 51-53,79,97-103 ;{ }^{\mathrm{c}}$ Ref 51-53,79,98,99,102,103; ${ }^{\mathrm{d}}$ Ref $72^{\mathrm{e}} \operatorname{Ref} 104$

Experimental studies show that pore diameter of MCM-41 material can be tailored in a wide range of values starting from 15 up to $100 \AA,^{51}$ depending on different factors, such as the surfactant used, $\mathrm{pH}$ of the solution, etc. However, typically the pore diameter for MCM-41 is $25-40 \AA . .^{51-53,97-103}$ Taking these data into account, we designed the pores in our models with a diameter (including silanols) between 27 $33 \AA$ A. This range also well corresponds to other theoretical studies. ${ }^{71-75}$ Hence, our first model of MCM41 material (A) was obtained by connecting three identical, slightly modified amorphous silica slabs ${ }^{55}$ and putting them into one hexagonal supercell (initial parameters $a=b=40 \AA, \mathrm{c}=13 \AA, \gamma=60^{\circ}$ ), forming a Y-type structure with an angle between the slabs of about $120^{\circ}$ (Figure 2 ). The empty space between three junctions (not connected slabs) was replaced by the $\mathrm{SiO}_{2}$ entities - forming a materialized connection within the junction areas and creating mainly four, five and six-membered-O-Si-O-Si-O- rings since they dominate on the surface of hydroxylated amorphous silica. This was performed manually. To obtain an optimizable model, some atoms were removed, added or there positions were changed. Eventually, the model constructed counts 456 atoms including $117 \mathrm{SiO}_{2}$ units and $35 \mathrm{H}_{2} \mathrm{O}$ molecules $\left(\mathrm{Si}_{117} \mathrm{O}_{269} \mathrm{H}_{70}\right)$. Then, the positions of all atoms were fully relaxed together with the unit cell dimensions, in order to minimalize energy of our new structure. Finally, the obtained model is characterized by the unit cell parameters of about $36 \AA \times 37 \AA \times 12 \AA$. The detailed information is given in the Table 1, whereas Figure 3 shows the hexagonal array of cylindrical pores obtained after multiplication of the unit cell. 


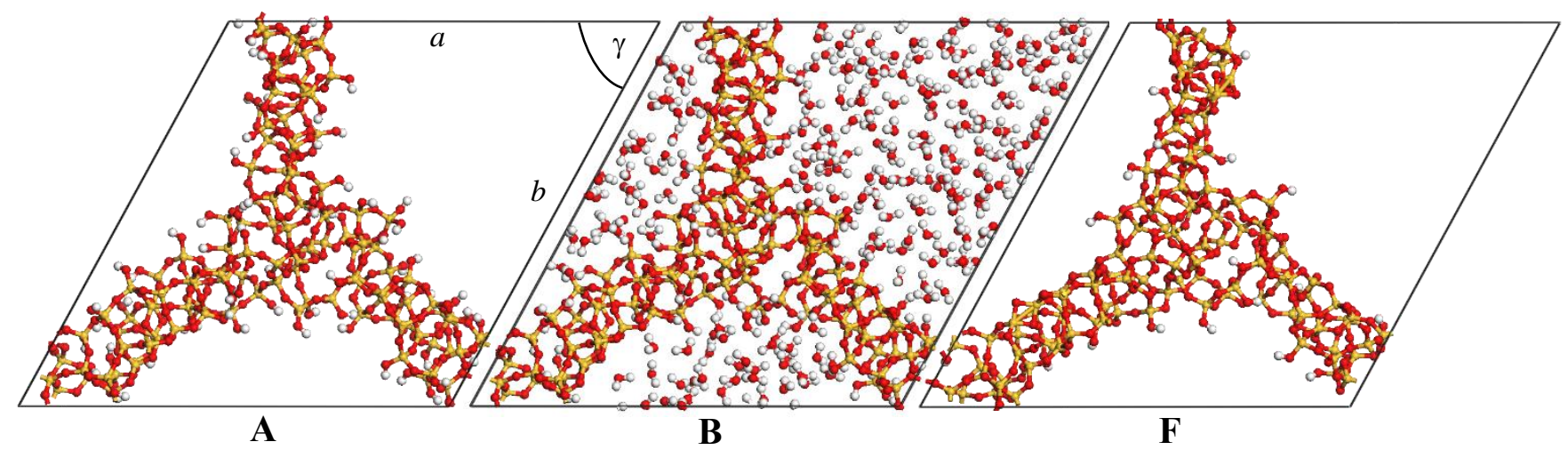

Figure 2. Detailed view of atoms belonging to the unit cell: model $\mathbf{A}\left(5.8 \mathrm{OH} \mathrm{nm}^{-2}\right)$, model $\mathbf{B}\left(5.8 \mathrm{OH} \mathrm{nm}^{-2}\right.$ with water adsorbed inside the pores) and model $\mathbf{F}\left(1.7 \mathrm{OH} \mathrm{nm}^{-2}\right)$ of MCM-41 mesoporous material.

A

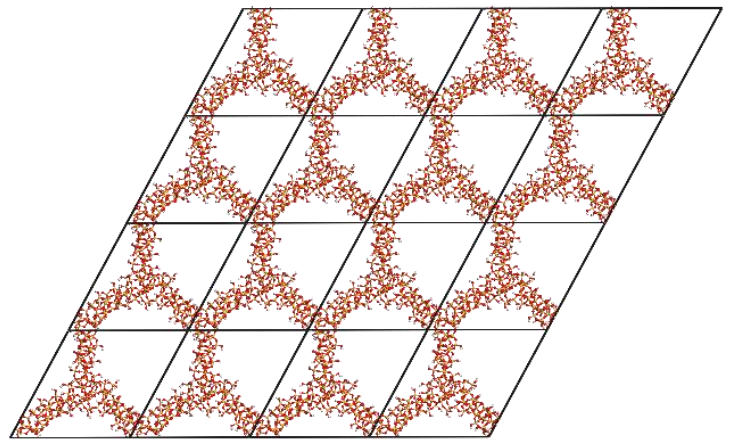

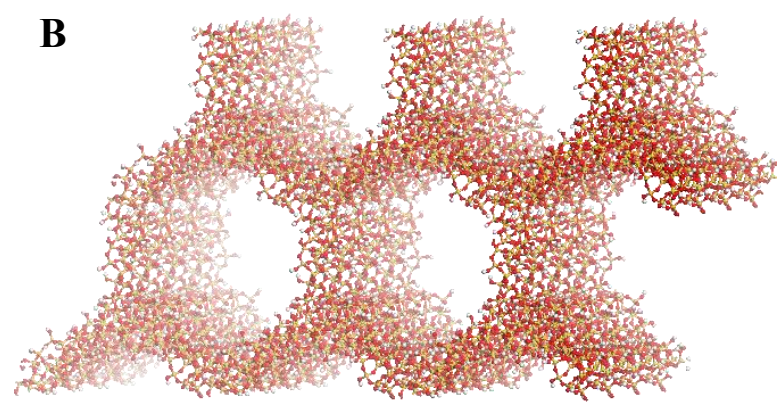

Figure 3. Hexagonal array of the cylindrical pores in the model A of MCM-41 mesoporous material: (A) 2D top view of the $4 \times 4 \times 1$ unit cell, (B) 3D view of the $3 \times 2 \times 4$ unit cell

It is well known that the walls of the real MCM-41 material are amorphous. Our models represent that feature, since we used our previously developed silica slab $^{55}$ which is amorphous. This previous model is used here as a building block and accounts for the experimentally encountered ring size distribution, Si-O$\mathrm{Si}$ and O-Si-O angles, silanols density, and silanols distribution of amorphous silica.

The wall thickness of our model A varies between $6-8 \AA$, which is comparable with the experimental data $(7$ - $30 \AA) .{ }^{51-53,98,99,102,103}$ Moreover, based on Monte Carlo simulations and experimental investigations, Maddox et al. ${ }^{71}$ suggested that the wall thickness of MCM-41 material is approximated to be smaller than $10 \AA$.

As far as the $\mathrm{T}$-site ( $\mathrm{SiO}_{4}$ tetrahedron) density is concerned, a value of $8.6 \mathrm{~T}$-site $\mathrm{nm}^{-3}$ is calculated, which correlates well with the models proposed by Ugliengo et al. $^{75}\left(8.2 \mathrm{~T}\right.$-site $\left.\mathrm{nm}^{-3}\right)$. It is also in accordance with previous models obtained through molecular mechanics or kinetic Monte Carlo simulation. ${ }^{71-74}$ Nevertheless, T-site density of the wall was also measured, i.e., density without including the volume of the pores, yielding $25.4 \mathrm{~T}$-site $\mathrm{nm}^{-3}$. This value is in agreement with the experimentally determined density for MCM-41 (27 T-site $\left.\mathrm{nm}^{-3}\right) .^{72}$ The calculated T-site density of the wall corresponds to wall density of 


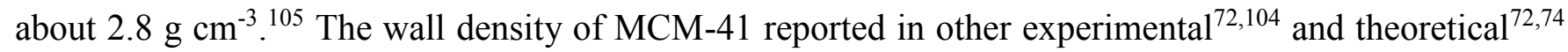
works are found to be in a range of $2.15-3.0 \mathrm{~g} \mathrm{~cm}^{-3}$, thus close to the results of our calculations.

An important structural property, that each model of amorphous silica should well predict, is the distribution of the siloxane ring sizes. Our model contains mainly four, five and six-membered rings, however, one can find some larger rings, i.e., containing seven and higher amount of $\mathrm{SiO}_{4}$ tetrahedra (Figure 4). The small three-membered rings are also present but they are (should be) in minority due to their high reactivity. As expected, two-membered rings are not seen, since they are too strained. ${ }^{4,55,106}$

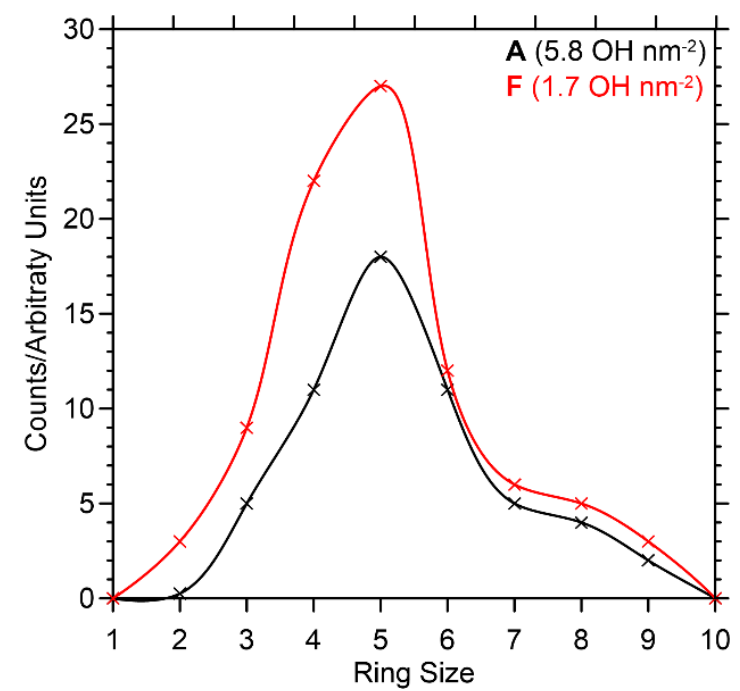

Figure 4. Ring size distribution in model $\mathbf{A}\left(5.8 \mathrm{OH} \mathrm{nm}^{-2}\right)$ and model $\mathbf{F}\left(1.7 \mathrm{OH} \mathrm{nm}^{-2}\right)$ of MCM-41 mesoporous material
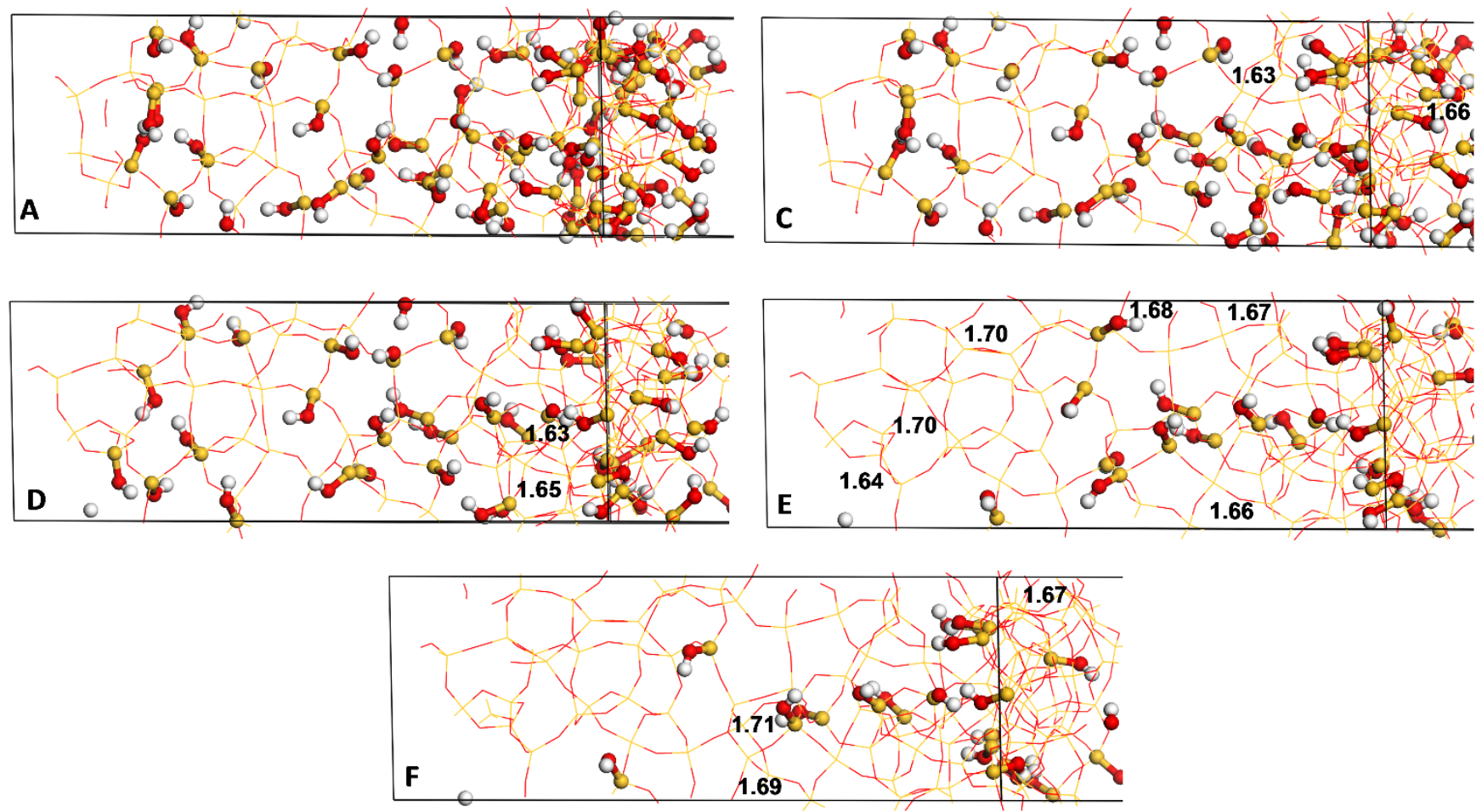

Figure 5. The wall structure of the MCM-41 models showing the Si-OH coverage and distance on selected sites. 
The average Si-O-Si distance in model $\mathbf{A}$ is about $1.64 \AA$, in agreement with the experimental data. For amorphous silica, the experimentally measured Si-O-Si distance is about $1.62 \AA^{107}$ whereas for MCM-41 it is about $1.60-1.61 .^{108-110}$

Similarly like in the case of our amorphous silica slab, ${ }^{55}$ the $\mathrm{Si}-\mathrm{O}-\mathrm{Si}$ angles range from nearly $103^{\circ}$ up to almost $180^{\circ}$. Smaller angles are related to the smaller rings, or they are caused by the deformation of the four- five- and six-membered ones. These results correlate well with the broad distribution of the $\mathrm{Si}-\mathrm{O}-\mathrm{Si}$ angle. $5,108,109$

The crucial feature of each type of silica, including also MCM-41, is the characteristics of the surface silanols, since they are responsible for chemical properties of the surface. Model A, with a surface silanol density of $5.8 \mathrm{OH} \mathrm{nm}^{-2}$, corresponds to our previous amorphous silica slab. ${ }^{55}$ The reported surface silanol density fits to the experimentally estimated amount of silanol groups on a hydroxylated surface of amorphous silicas at ambient conditions $\left(4.1-6.1 \mathrm{OH} \mathrm{nm}^{-2}\right) \cdot{ }^{12,111} \mathrm{It}$ is also close to the values reported explicitly for MCM-41 material at room temperature (RT), which is in the range of $4.4 \pm 0.5 \mathrm{OH} \mathrm{nm}^{-2}{ }^{13}$

Our next model (B) with $4.8 \mathrm{OH} \mathrm{nm}^{-2}$ fits even better to the experimentally determined silanols density, however, the one with $5.8 \mathrm{OH} \mathrm{nm}^{-2}$ can be defined as a fully hydroxylated MCM-41 structure that is stable at RT and spontaneously decomposes at elevated temperatures to give surface with $4.8 \mathrm{OH} \mathrm{nm}^{-2}$ (vide infra). In contrast, Ugliengo et al. ${ }^{75}$ developed MCM-41 model having $7.2 \mathrm{OH} \mathrm{nm}^{-2}$, which seems to be too high to account for adequate description of hydroxylated surface of this mesoporous silica material, especially at higher temperatures.

As far as different silanols types is concerned, about $89 \%$ of all $\mathrm{Si}-\mathrm{OH}$ groups in the model $\mathbf{A}$ are single silanols and $11 \%$ are geminal (Table 1), in accordance with the experimental estimation of germinal silanols (13\%) on the surface of amorphous silica at $453 \mathrm{~K}^{12,111}$. Among all 70 silanols, 40 are involved in H-bond contact (57\%), which is also consistent with the experimental data (61\%). ${ }^{12,11}$ The Si-OH distances on selected sites in the different models are reported in Figure 5.

\section{The effect of dehydroxylation and thermodynamics}

To simulate surface of MCM-41 material at different temperatures and water partial pressures, we developed models with 4.8, 3.6, 2.3 and $1.7 \mathrm{OH} \mathrm{nm}^{-2}$ (models $\mathbf{C - F}$ ), by removing 6, 13, 21, and 25 water molecules, respectively, relatively to the model A. The partial dehydroxylated models of MCM-41 material (C-F) were not arbitrary modelled, but can always be obtained from more hydroxylated ones by elimination of several $\mathrm{H}_{2} \mathrm{O}$ molecules. The nearest hydroxyls were condensed first to form siloxane bridges and $\mathrm{H}_{2} \mathrm{O}$ molecules. We started removing silanols that were involved in H-bond interaction and then - if it was necessary, non-H-bonded silanols - until the desired silanol coverage was achieved. Hence, we obtained 
our dehydroxylated models based on distance criteria only. Similar approach was used by other authors as well. ${ }^{14,75}$

Dehydroxylation of silica surface, including mesoporous structures, occurs over a wide range of temperature, ${ }^{12,13,111,112}$ so, the energy of each dehydroxylation step depends on the local environment of the leaving silanol group. Otherwise, all silanols would condense in a much narrower range. In particular, the amount of water molecules released form the surface as a result of silanols condensation should affect dehydroxylation energy, i.e., the more dehydroxylated model, the higher $\Delta E_{d e h}$. Indeed, according to our calculations (Table 2), the average energy required to remove $\mathrm{H}_{2} \mathrm{O}$ molecule from the model $\mathbf{A}(5.8 \mathrm{OH}$ $\left.\mathrm{nm}^{-2}\right)$ to give model $\mathbf{C}\left(4.8 \mathrm{OH} \mathrm{nm}^{-2}\right)$ is $42 \mathrm{~kJ} / \mathrm{mol}$, whereas to obtain the calcined model (model F) (1.7 $\mathrm{OH} \mathrm{nm}{ }^{-2}$ ) from model $\mathbf{A}$ is $137 \mathrm{~kJ} / \mathrm{mol}$. One should note that Ugliengo et al. ${ }^{75}$ observed similar trend for dehydroxylation of silica surface.

Table 2. Average dehydroxylation energy normalized per $\mathrm{H}_{2} \mathrm{O}$ molecule $\left(\Delta^{\mathrm{av}} E_{d e h}, \mathrm{~kJ} \mathrm{~mol}^{-1}\right)$ for each dehydroxylation step. The first four rows are the average energies relatively to model $\mathbf{A}$. The last three rows are the average energies for each step

\begin{tabular}{ll}
\hline reaction & $\Delta^{\text {av }} E_{d e h}$ \\
\hline $\mathbf{A} \rightarrow \mathbf{C}+6 \mathrm{H}_{2} \mathrm{O}$ & 42 \\
$\mathbf{A} \rightarrow \mathbf{D}+13 \mathrm{H}_{2} \mathrm{O}$ & 81 \\
$\mathbf{A} \rightarrow \mathbf{E}+21 \mathrm{H}_{2} \mathrm{O}$ & 128 \\
$\mathbf{A} \rightarrow \mathbf{F}+25 \mathrm{H}_{2} \mathrm{O}$ & 137 \\
$\mathbf{C} \rightarrow \mathbf{D}+7 \mathrm{H}_{2} \mathrm{O}$ & 115 \\
$\mathbf{D} \rightarrow \mathbf{E}+8 \mathrm{H}_{2} \mathrm{O}$ & 205 \\
$\mathbf{E} \rightarrow \mathbf{F}+4 \mathrm{H}_{2} \mathrm{O}$ & 180
\end{tabular}
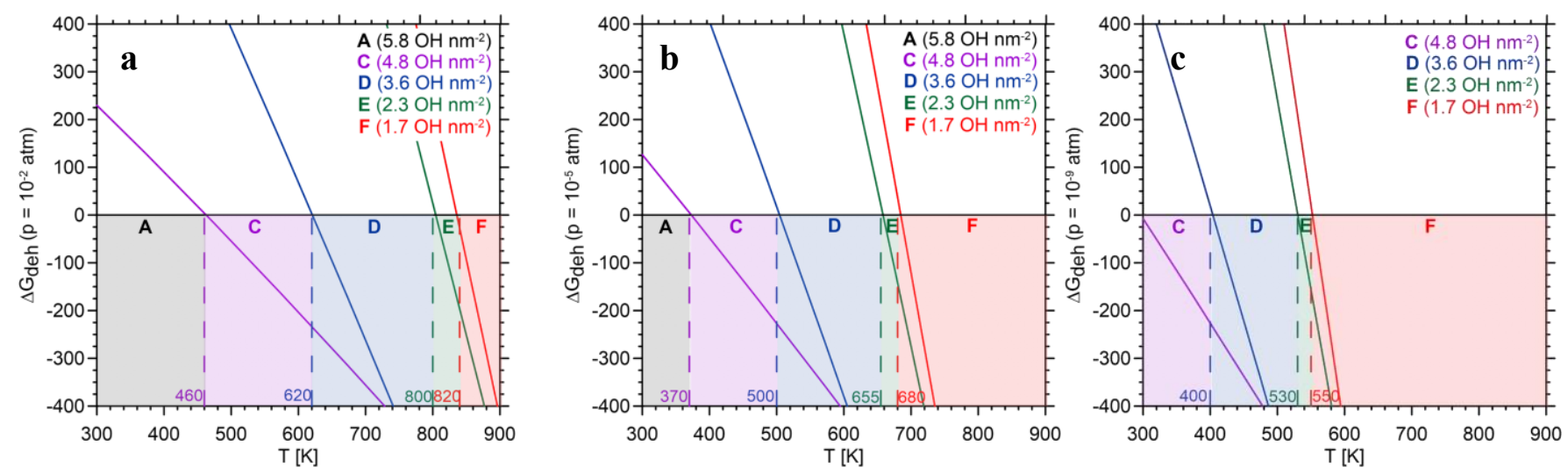

Figure 6 Diagrams (Gibbs energy of dehydroxylation vs. temperature) showing stability of each dehydroxylated models of MCM-41 material at different water partial pressure: a) $10^{-2} \mathrm{~atm}$, b) $10^{-5} \mathrm{~atm}$ c) $10^{-9} \mathrm{~atm}$. 
Figure 6 shows the stability of each dehydroxylated model of MCM-41 studied, in terms of Gibbs energy of dehydroxylation as a function of temperature and pressure. The water partial pressure equivalent to ambient air water partial pressure was chosen equal to $10^{-2}$ atm. ${ }^{113}$ Additionally, the stability of each model is also presented at $10^{-5}$ atm and $10^{-9}$ atm. Considering dehydroxylation at $10^{-2}$ atm (Figure 5 a), dehydroxylation of model A may occur to generate a surface with $4.8 \mathrm{OH} \mathrm{nm}^{-2}$ (model $\mathbf{C}$ ), which is stable above $460 \mathrm{~K}$. At about $620 \mathrm{~K}$, formation of the surface having $3.6 \mathrm{OH} \mathrm{nm}$ (D) becomes thermodynamically favored. Further temperature increasing up to above about $800 \mathrm{~K}$ facilitates formation of more dehydroxylated model $\mathbf{E}$ with the silanols density of $2.3 \mathrm{OH} \mathrm{nm}^{-2}$. Finally, the calcined surface (model F), characterized by the silanols coverage of $1.7 \mathrm{OH} \mathrm{nm}^{-2}$, is stable above $820 \mathrm{~K}$. These results are in good agreement with the experimental studies of Zhuravlev ${ }^{12,111}$ on amorphous silica, as well as Gallas et al. ${ }^{13}$ explicitly for MCM-41. One should note that surface of amorphous silica is not the same as surface of mesoporous material, however, the silanols coverage at different temperatures in both cases are quite close to each other. Additionally, for MCM-41 the most of data are related to the silanols density after high-temperature calcination, which is usually carried out at about 800-900 K. For that temperatures, experimentally determined silanols density is about $1.6-2.3 \mathrm{OH} \mathrm{nm}^{-2},{ }^{13,79,100,102,114}$ however, $0.8 \mathrm{OH} \mathrm{nm}^{-}$ ${ }^{2},{ }^{115}$ as well as up to $3 \mathrm{OH} \mathrm{nm}^{-2} 112$ is also reported. At lower water partial pressure (Figure $6 \mathrm{~b}$, c), which are more typical in experimental studies ${ }^{13,79}$, stability of our models are shifted towards lower temperatures. One should note that the presented values are reported for equilibrium state which might be hardly achievable during experiments.

The basic properties of each dehydroxylated models do not change significantly. Because of that, we will only discuss here the calcined model F (Figure 2).

After releasing 25 water molecules form $\mathbf{A}$ the pore size diameter (including silanol groups) becomes slightly longer, wall density is smaller, whereas wall thickness remains almost unchanged (Table 1). This is in agreement with the high number of silanol pairs which were removed from the surface. Experimental studies suggest ${ }^{12,111}$ that most of silanols that still remain on the surface after high temperature calcination are isolated (non-H-bonded). This well agrees with our results (Table 1) where among all 20 silanols, only $35 \%$ are involved in $\mathrm{H}$-bond contact with neighboring siloxane bridges. Additionally, none of the silanols interact with other Si-OH groups, because they are well dispersed now. According to our model, geminal silanols are not presented on the surface at high temperature, in agreement with the experimentally determined dominance of single silanols. ${ }^{78}$

Silanols condensation increases number of -O-Si-O-Si-O- rings in the MCM-41 material. Our calculations suggest, that after high-temperature calcination, mainly three-, four- and five- membered rings are formed, whereas number of larger rings remains almost unchanged, in comparison to the model A (Figure 4). A 
few strained two-membered rings are also present. Nevertheless, the ring size distribution is similar to that for the model $\mathbf{A}$ with $5.8 \mathrm{OH} \mathrm{nm}^{-2}$.

\section{The solvated model}

Having prepared several models of MCM-41 material, which describe properties of this mesoporous silica at different temperatures, next we study this system with water molecules adsorbed inside the pores. To this end, the pores of previously developed model A (stable at RT) were filled with 213 water molecules randomly oriented and located. The number of water molecules corresponds to the experimentally determined amount of $\mathrm{H}_{2} \mathrm{O}$ adsorbed in cylindrical pores of MCM-41 material (about 0.5 g $\mathrm{H}_{2} \mathrm{O} / 1 \mathrm{~g} \mathrm{MCM}$ 41) 115 . Hence, including the average pore size diameter of about $30 \AA$, the density of water in the pores is about $0.7 \mathrm{~g} \mathrm{~cm}^{-3}$. The obtained value is quite close to the results of other studies. ${ }^{113}$ Then, the whole system was fully relaxed with fixed unit cell dimensions. As a result, model $\mathbf{B}$ with the molecular formula $\mathrm{Si}_{117} \mathrm{O}_{482} \mathrm{H}_{496}$ (1095 atoms in unit cell) were obtained (Figure 2). In this model, the same unit cell dimensions, silanols density, silanols type distribution, pore diameter, wall thickness, wall density and geometric parameters was found as for model $\mathbf{A}$ (Table 1).

As expected, most of the 30 non-interacting silanols of the model $\mathbf{A}$ are now (model $\mathbf{B}$ ) involved in $\mathrm{H}$ bond contact with water molecules, either as a donor or an acceptor of hydrogen bond. After filling the pores with the water molecules, most of the remaining 40 silanols, which were involved in H-bond interaction with other silanols or siloxane bridges in the model $\mathbf{A}$, still remain interacting with each other (model B). Nevertheless, some of them are also able to create new H-bond with water molecules, finally giving 37 silanols on a total 70, on which the water is adsorbed. Further analysis showed that 7 silanols are able to interact with two water molecules at once and none with more than two. Water molecule can be also adsorbed on two neighboring silanols (two $\mathrm{H}_{2} \mathrm{O}$ molecules in our model). It is clear that as far as the water silica interface is concerned a molecular dynamics study should be performed similar to our former studies on a silica slab model. ${ }^{105,116}$

The average binding energy of $\mathrm{H}_{2} \mathrm{O}$ molecule in the model $\mathrm{B}$ is $54 \mathrm{~kJ} / \mathrm{mol}$, whereas in recent paper ${ }^{55}$ it was 46-50 kJ/mol. Hence, the results obtained for MCM-41 models and silica slab are comparable. Taking dispersion interaction into account, the average binding energy of $\mathrm{H}_{2} \mathrm{O}$ in the model $\mathrm{B}$ is $64 \mathrm{~kJ} / \mathrm{mol}$.

\section{The vibrational properties}

In order to further verify our models of MCM-41 material, we have simulated the IR spectra of systems $\mathbf{A}$, $\mathbf{B}$ and $\mathbf{F}$ in the extended $\mathrm{OH}$ stretching frequencies region $\left(4000-2000 \mathrm{~cm}^{-1}\right)$. The obtained results are summarized in Figure 6. One should note that comparison with experimental data ${ }^{13,118}$ is not straightforward, because the shapes and shifts of calculated spectra (Fig. 7) are different. This is because 
we do not scale nor fit the frequencies like it was done elsewhere, ${ }^{75,77,78}$ so, quantitative comparison with experiments is a difficult task. On the other hand, more important is the qualitative comparison. In that case, our results simulate very well experimental data, since the position of all bands are in a good agreement with experiments.

Starting from the simulated spectra of model $\mathbf{A}$, it is seen that the $\mathrm{OH}$ stretching vibrations occur between $3821-3033 \mathrm{~cm}^{-1}$, which can be divided into three domains. The highest values $\left(3821-3787 \mathrm{~cm}^{-1}\right) \mathrm{are}$ calculated for non H-bonded silanols. Then, we observe a domain $\left(3787-3699 \mathrm{~cm}^{-1}\right)$ corresponding to either H-bonded acceptor or non-H-bonded silanols. The third domain is the broadest, and lies between 3699 and $3033 \mathrm{~cm}^{-1}$, and corresponds to the H-bonded donor silanols. Additionally, it is also worth to mention, that each $-\mathrm{OH}$ moiety of $\mathrm{H}$-bonded geminal silanols do not vibrate with the same wavenumber, due to different interaction with neighboring silanols. Our results correlates very well with the spectra of real MCM-41 material. Experimentally, sharp bands are observed between $3747-3737 \mathrm{~cm}^{-1}$ which are assigned to non-H-bonded silanols ${ }^{13,112,118-120}$, the bands at around $3715 \mathrm{~cm}^{-1} 118,119$ to H-bonded acceptor silanols, whereas the broadest bands, with the maximum at around $3536-3520 \mathrm{~cm}^{-1}$ are assigned to Hbonded silanols, either acceptors or donors ${ }^{13,118,119}$.
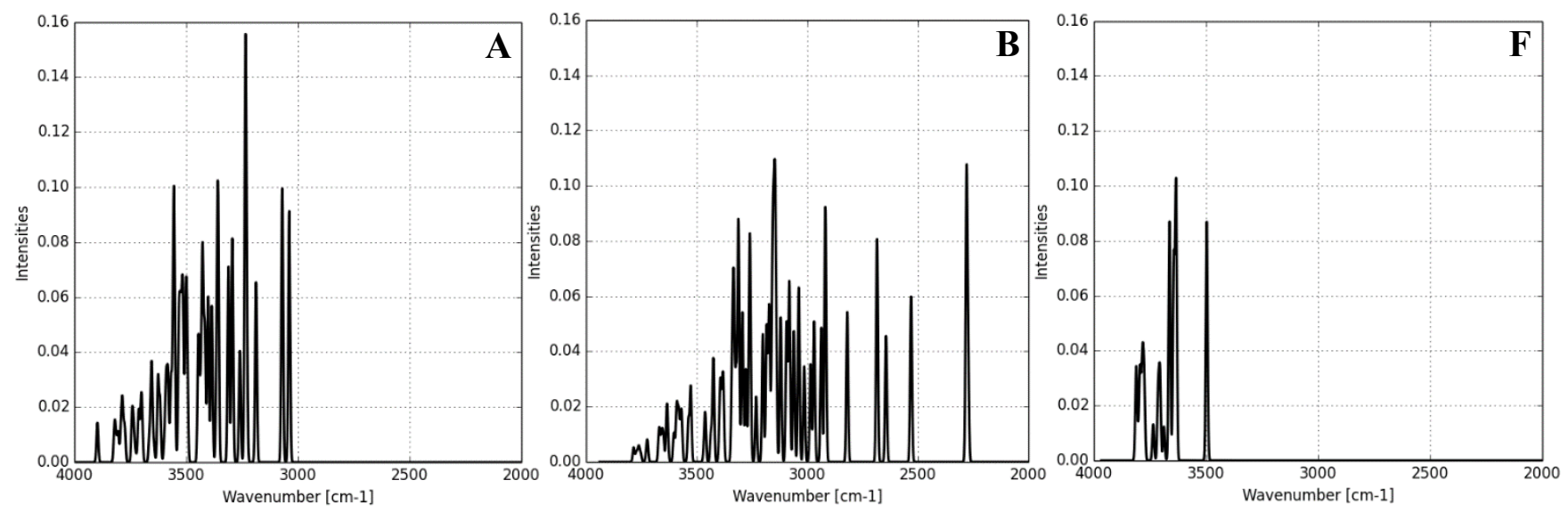

Figure 7. Simulated IR spectra of model $\mathbf{A}\left(5.8 \mathrm{OH} \mathrm{nm}^{-2}\right)$, model $\mathbf{B}\left(5.8 \mathrm{OH} \mathrm{nm}{ }^{-2}\right.$ with water adsorbed inside the pores $)$ and model $\mathbf{F}\left(1.7 \mathrm{OH} \mathrm{nm}^{-2}\right)$ of MCM-41 mesoporous material.

For model B (Figure 7) the simulated spectra becomes broader (3776-2207 $\mathrm{cm}^{-1}$ ). Not surprising, since the H-bond network is much complex now due to the presence of water. Again, the calculated vibrational frequencies can be divided into three domains. The non-H-bonded silanols vibrate at $3776-3759 \mathrm{~cm}^{-1}$, whereas silanols that are acceptors of H-bonds, either from other silanols or adsorbed water molecules vibrate at $3759-3525 \mathrm{~cm}^{-1}$. The third domain, occurring over wide range of wavenumbers $\left(3525-2207 \mathrm{~cm}^{-}\right.$ $\left.{ }^{1}\right)$ corresponds to the silanols that are donors of H-bonds to other silanols, siloxane bridges or water molecules. Hence, after filling the pores of MCM-41 material by water, the $\mathrm{OH}$ stretching vibrations becomes redshifted as one may expected. One should note that the bands of H-bonded silanols overlap by 
with the signal from water aggregates adsorbed on the surface. The latter are experimentally detected between $3600-2700 \mathrm{~cm}^{-1}{ }^{117}$

In the case of the model representing MCM-41 material after high-temperature calcination (Figure 2, model F), narrow spectra are simulated (Figure 7), with the $\mathrm{OH}$ stretching frequencies region of $3826-3503 \mathrm{~cm}^{-}$ ${ }^{1}$. The bands at $3826-3791 \mathrm{~cm}^{-1}$ correspond to non-H-bonded single silanols, whereas at $3791-3503 \mathrm{~cm}^{-1}$ to silanols being donor of $\mathrm{H}$-bond to siloxane bridges.

\section{$\underline{\mathrm{Ab} \text { Initio Molecular Dynamics investigation of the interfacial water layer. }}$}

In the static models, after optimization, no information is given on the mobility of the water molecules inside the channels. In order to shed some light on the dynamical properties of water, we performed a AIMD including dispersion corrections. One of the questions to ask is: Can we rationalize the water mobility towards its positon in the channel? Previously, the water/ $\mathrm{SiO}_{2}$ interface has been studied in detail at the AIMD level ${ }^{106,117}$ and at the FFMD level ${ }^{45-48}$. It is not the aim here to develop this point in detail, however some remarks are interesting to be mentioned. When DFT results are compared with empiric FF results important differences are observed. Especially the interaction of the water molecules with the surface silanol groups. In DFT studies the "ice like structure" of the first water layer at the surface is observed whereas in FF the water molecules are found to be more mobile. Nevertheless, one should mention here the experimentally observed high affinity of water towards the hydroxylated silica surface, especially observed in when water is competing with amino acids. ${ }^{67}$ In order to find any explanation one should answers to questions involving the following parameters: Time scale, FF and functional quality, size of the model, confinement, the silanol density and distribution. Here we present in short our results on the MCM-41 model which agrees, without any surprise with the Silica slab model. ${ }^{55,117}$

The first water layer is strongly adsorbed on the silica wall of the MCM-41 channel having a silanol density of $5.8 \mathrm{OH} / \mathrm{nm}^{-2}$, as can be seen in Figure 8, the blue colored water molecules in the model stay close to the channel surface and do not diffuse for a sampling time up to 8 ps. 

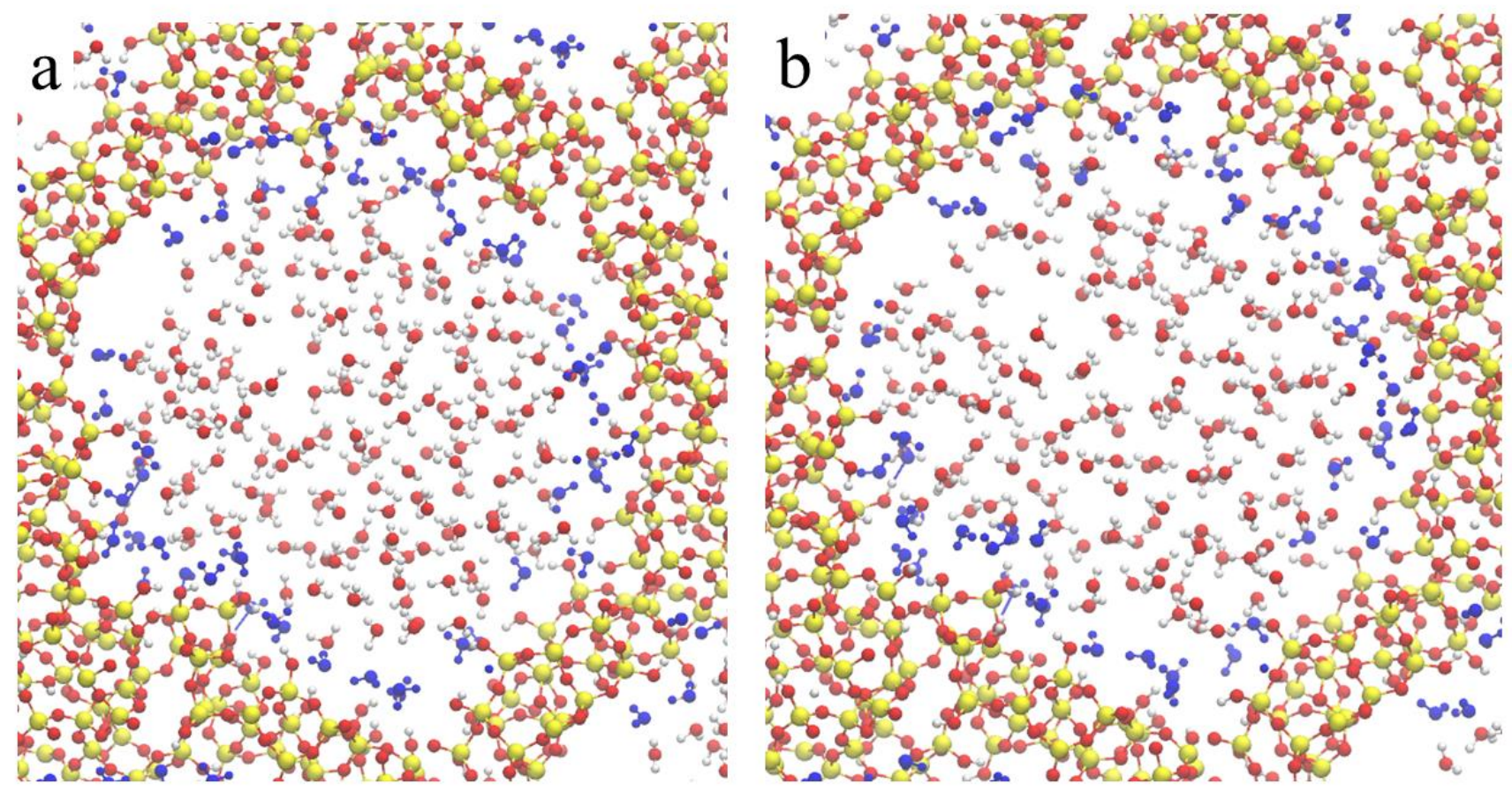

Figure 8. Snap shot of the MD at 300K a) when potential energy equilibration is reached (after $3 \mathrm{ps}$ ), b) after 6,5 ps equilibration.

The mobility of the first shell of water around the silica is qualitatively very low as is shown in Fig 8 . The water molecules of the first shell displayed in blue at the time $3 \mathrm{ps}$ after the equilibration. The snapshot after 6.5 ps shows that the water shell is almost identical to the one after 3 ps.

In Figure 9 the distance distribution between silicon and hydrogen atoms is presented. The fist peak around 2.3 correspond to the $\mathrm{Si}-\mathrm{H}$ distance of the silanol groups. The second peak between 3.3 and 4.5 corresponds to the fist shell of hydration. Its bright is interpreted by the large number of different of silanol groups involving several kinds of hydrogen bonds. 


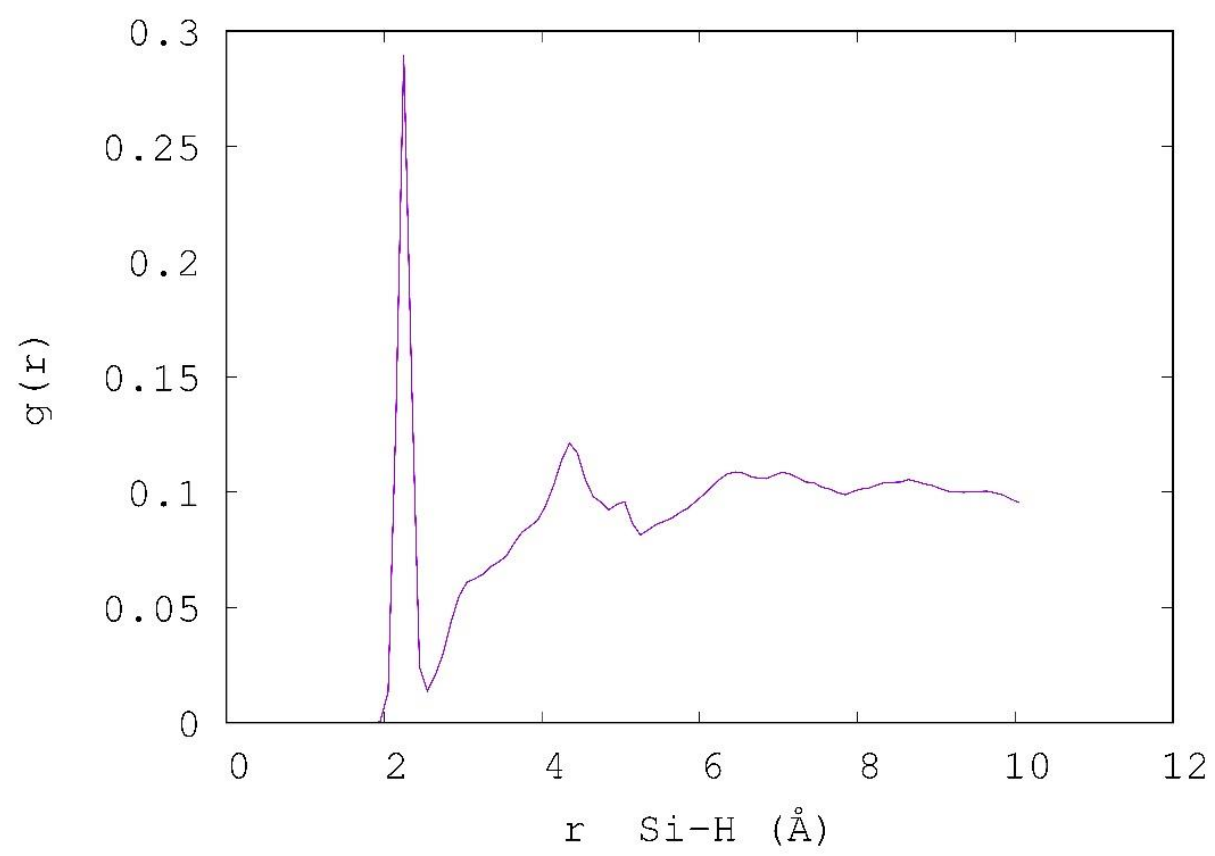

Figure 9. Distance distribution between $\mathrm{Si}$ and $\mathrm{H}$ atoms in the hydrated model.

The distance distribution between the $\mathrm{O}$ and $\mathrm{H}$ atoms is presented in Fig 10. The peak around $1 \AA$ corresponds to the SiO-H covalent bonds, the second around $1.8 \AA$ to the hydrogen bonds (water - water and silanol and water), the third at $3.3 \AA$ to Si-O1-H1 ... O2-H2 distance.

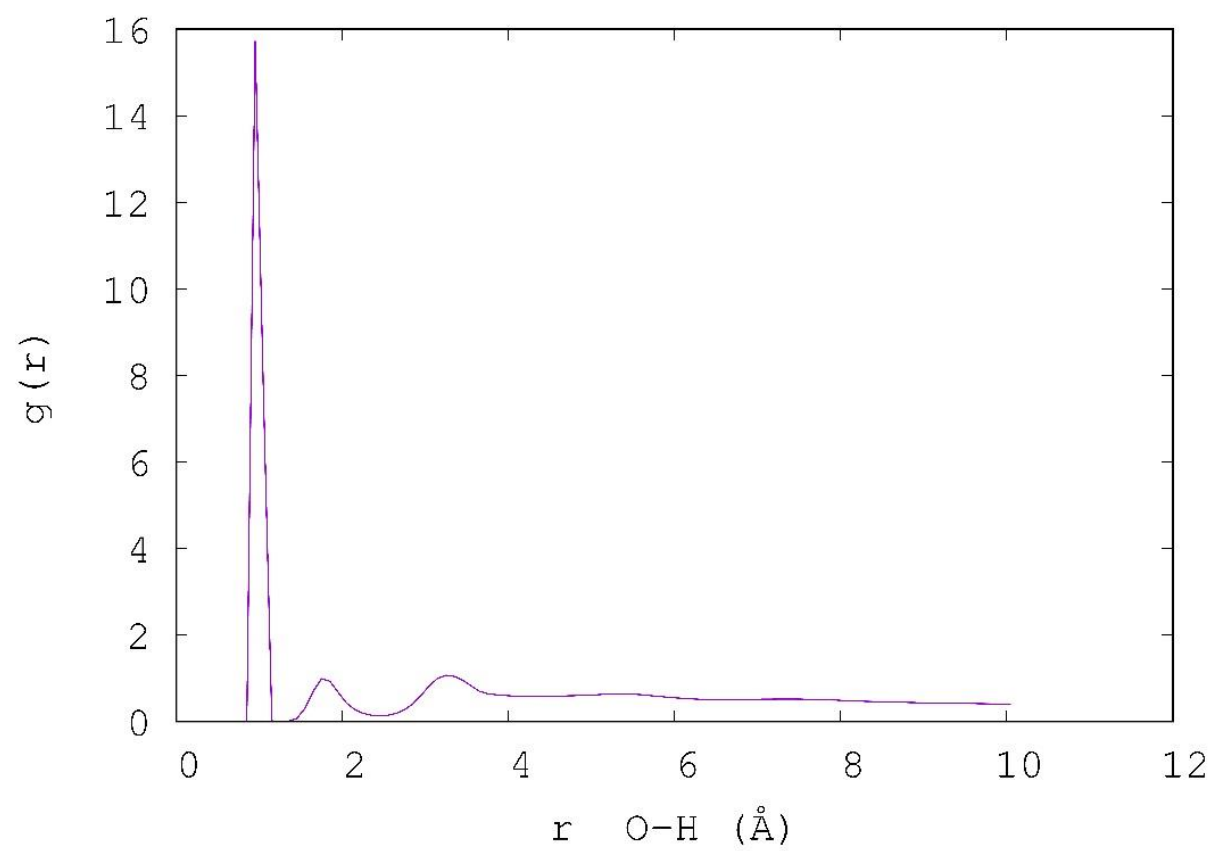

Figure 10. Distance distribution between $\mathrm{O}$ and $\mathrm{H}$ atoms in the hydrated model. 
More details of the AIMD analysis concerning the radial distribution functions can be found in the Supplementary Information.

\section{CONCLUSION}

In this work, a series of periodic models are presented to describe properties of MCM-41 mesoporous silica - an important material and a popular catalyst support. We have prepared and verified six models of MCM41 that follow temperature dependence of silanols density. In particular, models with 5.8, 5.8 with water inside the pores, 4.8, 3.6, 2.3 and $1.7 \mathrm{OH} \mathrm{nm}^{-2}$ have been developed. We have shown that our models represent very well the surface of real MCM-41 silica, as evidenced by the comparison with available experimental data, and are improved compared with earlier published models ${ }^{70-74}$. The simulated IR spectra additionally confirms that our models are realistic. For the first time such comprehensive theoretical studies, including the high level of theory and AIMD, have been performed for MCM-41 material. Comparing our models of MCM-41 material to that published by Ugliengo et al. ${ }^{74}$ it is worth to note that in our model the unit cell dimensions as well as the number of atoms belonging to the cell is smaller, and thus more suited for applicative calculations due to less demanding computational power. Hence, we believe the models developed in this work can be applied in further studies of adsorption processes or they can be used in the modelling of the catalyst supports, because they are realistic and enable effective computation in reasonable time. 


\section{ACKNOWLEDGEMENTS}

This work was supported in part by the National Science Centre, Poland, Project. No. 2015/19/N/ST4/00007 and 2015/19/B/ST4/01836, and by French state funds managed by the ANR within the Investissements d'Avenir programme under reference ANR-11-IDEX-0004-02, and more specifically within the framework of the Cluster of Excellence MATISSE led by Sorbonne Université. HPC resources from GENCI-[CCRT/CINES/IDRIS] (Grant 2015-[x2015082022]) and the CCRE of Université Pierre et Marie Curie are also acknowledged. Other computational resources from PL-Grid Infrastructure are acknowledged as well.

\section{NOTES}

The coordinates of all the structures developed in this work are available in the Supplementary Information.

\section{REFERENCES}

1 T. Bakos, S. N. Rashkeev and S. T. Pantelides, Phys. Rev. Lett., 2002, 88, 055508-1-055508-4.

2 A. P. Legrand, The Surface Properties of Silicas, Wiley, New York, 1998.

3 R. K. Iler, The Chemistry of Silicas, Wiley, New York, 1979.

4 A. Rimola, D. Costa, M. Sodupe, J. F. Lambert and P. Ugliengo, Chem. Rev., 2013, 113, 42164313.

5 F. Tielens, F. De Proft and P. Geerlings, J. Mol. Struct. THEOCHEM, 2001, 542, 227-237.

6 L. T. Zhuravlev, Langmuir, 1987, 3, 316-318.

7 M. Nishijima, K. Edamoto, Y. Kubota, S. Tanaka and M. Onchi, J. Chem. Phys., 1986, 84, 6458.

8 V. Bolis, B. Fubini, L. Marchese, G. Martra and D. Costat, J. Chem. Soc. Faraday Trans., 1991, 87, 497-505.

9 D. W. Sindorf and G. E. Maciel, J. Am. Chem. Soc., 1983, 105, 1487-1493.

10 A. S. D’Souza and C. G. Pantano, J. Am. Ceram. Soc., 2002, 85, 1499-1504.

11 S. Wendt, M. Frerichs, T. Wei, M. S. Chen, V. Kempter and D. W. Goodman, Surf. Sci., 2004, 565, 107-120.

12 L. T. Zhuravlev, Colloids Surfaces A, 2000, 173, 1-38.

13 J. P. Gallas, J. M. Goupil, A. Vimont, J. C. Lavalley, B. Gil, J. P. Gilson and O. Miserque, Langmuir, 2009, 25, 5825-5834.

14 A. Comas-Vives, Phys. Chem. Chem. Phys., 2016, 18, 7475-7482.

15 B. A. Morrow and A. J. McFarlan, J. Phys. Chem., 1992, 96, 1395-1400.

16 P. Van Der Voort, I. Gillis-D’Hamers, K. C. Vrancken and E. F. Vansant, J. Chem. Soc. Faraday Trans., 1991, 87, 3899-3905. 
B. Riegel, I. Hartmann, W. Kiefer, J. Groß and J. Fricke, J. Non-Cryst. Solids, 1997, 211, 294-298.

A. Pasquarello and R. Car, Phys. Rev. Lett., 1998, 80, 5145-5147.

G. E. Maciel and D. W. Sindorf, J. Phys. Chem., 1980, 102, 7607-7608.

S. Léonardelli, L. Facchini, C. Fretigny, P. Tougne and A. P. Legrand, J. Am. Chem. Soc., 1992, 114, 6412-6418.

21 A. Tuel, H. Hommel, A. P. Legrand and E. sz. Kováts, Langmuir, 1990, 6, 770-775.

22 C. C. Liu and G. E. Maciel, J. Am. Chem. Soc., 1996, 118, 5103-5119.

23 H. Eckert, J. P. Yesinowski, L. A. Silver and E. M. Stolper, J. Phys. Chem., 1988, 92, 2055-2064.

24 C. E. Bronnimann, R. C. Zeigler and G. E. Maciel, J. Am. Chem. Soc., 1988, 110, 2023-2026.

25 I.-S. Chuang and G. E. Maciel, J. Am. Chem. Soc., 1996, 118, 401-406.

26 D. R. Kinney, I.-S. Chuang and G. E. Maciel, J. Am. Chem. Soc., 1993, 115, 6786-6794.

27 D. Freude, M. Hunger and H. Pfeifer, Chem. Phys. Lett., 1982, 91, 307-310.

28 S. Haukka, E.-L. Lakomaa and A. Root, J. Phys. Chem., 1993, 97, 5085-5094.

29 D. F. Shantz, J. S. auf der Günne, H. Koller and R. F. Lobo, J. Am. Chem. Soc., 2000, 122, 66596663.

J. Trébosc, J. W. Wiench, S. Huh, V. S.-Y. Lin and M. Pruski, J. Am. Chem. Soc., 2005, 127, 30573068 .

31 B. P. Feuston and S. H. Garofalini, J. Appl. Phys., 1990, 68, 4830-4836.

32 S. H. Garofalini, J. Non-Cryst. Solids, 1990, 120, 1-12.

33 L. V. Woodcock, C. A. Angell and P. Cheeseman, J. Chem. Phys., 1976, 65, 1565-1577.

34 T. F. Soules, J. Chem. Phys., 1979, 71, 4570-4578.

35 S. K. Mitra, M. Amini, D. Fincham and R. W. Hockney, Philos. Mag. Part B, 1981, 43, 365-372.

36 J. D. Kubicki and A. C. Lasaga, Am. Mineral., 1988, 73, 941-955.

37 E. S. Savoy and F. A. Escobedo, J. Colloid Interface Sci., 2016, 465, 233-241.

38 H. Heinz, Curr. Opin. Chem. Eng., 2016, 11, 34-41.

39 F. S. Emami, V. Puddu, R. J. Berry, V. Varshney, S. V. Patwardhan, C. C. Perry and H. Heinz, Chem. Mater., 2014, 26, 2647-2658.

40 F. S. Emami, V. Puddu, R. J. Berry, V. Varshney, S. V. Patwardhan, C. C. Perry and H. Heinz, Chem. Mater., 2016, 28, 406-407.

41 S. Nedd, T. Kobayashi, C. H. Tsai, I. I. Slowing, M. Pruski and M. S. Gordon, J. Phys. Chem. C, 2011, 115, 16333-16339.

42 V. A. Bakaev and W. A. Steele, J. Chem. Phys., 1999, 111, 9803-9812.

43 E. A. Leed and C. G. Pantano, J. Non-Cryst. Solids, 2003, 325, 48-60.

44 E. A. Leed, J. O. Sofo and C. G. Pantano, Phys. Rev. B, 2005, 72, 155427-1-155438-11. 
D. Laage and W. H. Thompson, J. Chem. Phys., 2012, 136, 044513-1-044513-7.

A. C. Fogarty, E. Duboué-Dijon, D. Laage and W. H. Thompson, J. Chem. Phys., 2014, 141, 18C523-1-18C523-10.

47 P. C. Burris, D. Laage and W. H. Thompson, J. Chem. Phys., 2016, 144, 194709.

48 S. Xiao, F. Figge, G. Stirnemann, D. Laage and J. A. McGuire, J. Am. Chem. Soc., 2016, 138, 55515560.

49 A. A. Hassanali and S. J. Singer, J. Phys. Chem. B, 2007, 111, 11181-11193.

50 C. S. Ewing, S. Bhavsar, G. Veser, J. J. McCarthy, and J. K. Johnson, Langmuir 2014, 30, 5133-5141

51 J. S. Beck, J. C. Vartuli, W. J. Roth, M. E. Leonowicz, C. T. Kresge, K. D. Schmitt, C. T. W. Chu, D. H. Olson, E. W. Sheppard, S. B. McCullen, J. B. Higgins and J. L. Schlenker, J. Am. Chem. Soc., 1992, 114, 10834-10843.

52 C. T. Kresge, M. E. Leonowicz, W. J. Roth, J. C. Vartuli and J. S. Beck, Nature, 1992, 359, 710712.

53 P. T. Tanev and T. J. Pinnavaia, Science, 1995, 267, 865-867.

54 M. Hartmann, Chem. Mater., 2005, 17, 4577-4593.

55 F. Tielens, C. Gervais, J. F. Lambert, F. Mauri and D. Costa, Chem. Mater., 2008, 20, 3336-3344.

56 H. Guesmi and F. Tielens, J. Phys. Chem. C, 2012, 116, 994-1001.

57 J. Handzlik, R. Gryboś and F. Tielens, J. Phys. Chem. C, 2013, 117, 8138-8149.

58 M. Gierada, P. Michorczyk, F. Tielens and J. Handzlik, J. Catal., 2016, 340, 122-135.

59 H. Guesmi, R. Gryboś, J. Handzlik and F. Tielens, Phys. Chem. Chem. Phys., 2014, 16, $18253-$ 18260.

60 H. Guesmi, R. Gryboś, J. Handzlik and F. Tielens, RCS Adv., 2016, 6, 39424-39432.

61 M. M. Islam, D. Costa, M. Calatayud and F. Tielens, J. Phys. Chem. C, 2009, 113, 10740-10746.

62 D. C. Tranca, A. Wojtaszek-Gurdak, M. Ziolek and F. Tielens, Phys. Chem. Chem. Phys., 2015, 17, 22402-22411.

63 A. Wojtaszek, I. Sobczak, M. Ziolek and F. Tielens, J. Phys. Chem. C, 2009, 113, 13855-13859.

64 A. Wojtaszek, I. Sobczak, M. Ziolek and F. Tielens, J. Phys. Chem. C, 2010, 114, 9002-9007.

65 D. Costa, A. Tougerti, F. Tielens, C. Gervais, L. Stievano and J. F. Lambert, Phys. Chem. Chem. Phys., 2008, 10, 6360.

66 D. Costa, F. Tielens, L. Stievano and J. F. Lambert, AIP Conf. Proc., 2009, 1102, 251-256.

67 N. Folliet, C. Gervais, D. Costa, G. Laurent, F. Babonneau, L. Stievano, J. F. Lambert and F. Tielens, J. Phys. Chem. C, 2013, 117, 4104-4114.

68 N. Folliet, C. Roiland, S. Bégu, A. Aubert, T. Mineva, A. Goursot, K. Selvaraj, L. Duma, F. Tielens, 
F. Mauri, G. Laurent, C. Bonhomme, C. Gervais, F. Babonneau and T. Azaïs, J. Am. Chem. Soc., 2011, 133, 16815-16827.

M.-A. Neouze, M. Kronstein, M. Litschauer, M. Puchberger, C. Coelho, C. Bonhomme, C. Gervais and F. Tielens, Chem. - A Eur. J., 2014, 20, 15188-15196.

M.-A. Neouze, M. Kronstein and F. Tielens, Chem. Commun., 2014, 50, 10929-10936.

B. P. Feuston and J. B. Higgins, J. Phys. Chem., 1994, 98, 4459-4462.

M. W. Maddox, J. P. Olivier and K. E. Gubbins, Langmuir, 1997, 13, 1737-1745.

S. Schacht, M. Janicke and F. Schüth, Micropor. Mesopor. Mater., 1998, 22, 485-493.

C. Schumacher, J. Gonzalez, P. A. Wright and N. A. Seaton, J. Phys. Chem. B, 2006, 110, 319-333.

P. Ugliengo, M. Sodupe, F. Musso, I. J. Bush, R. Orlando and R. Dovesi, Adv. Mater., 2008, 20, 4579-4583.

B. Coasne and P. Ugliengo, Langmuir, 2012, 28, 11131-11141.

M. Delle Piane, M. Corno, A. Pedone, R. Dovesi and P. Ugliengo, J. Phys. Chem. C, 2014, 118, $26737-26749$.

M. Delle Piane, M. Corno and P. Ugliengo, Theor. Chem. Acc., 2016, 135, 53-63.

M. Ide, M. El-Roz, E. De Canck, A. Vicente, T. Planckaert, T. Bogaerts, I. Van Driessche, F. Lynen, V. Van Speybroeck, F. Thybault-Starzyk and P. Van Der Voort, Phys. Chem. Chem. Phys., 2012, $15,642-650$.

J. P. Perdew, K. Burke and M. Ernzerhof, Phys. Rev. Lett., 1996, 77, 3865-3868.

81 G. Kresse and J. Hafner, Phys. Rev. B, 1993, 47, 558-561.

82 G. Kresse and J. Furthmüller, Comput. Mater. Sci., 1996, 6, 15-50.

83 G. Kresse and J. Furthmüller, Phys. Rev. B, 1996, 54, 11169-11186.

84 P. E. Blöchl, O. Jepsen and O. K. Andersen, Phys. Rev. B, 1994, 49, 16223-16233.

85 G. Kresse and D. Joubert, Phys. Rev. B, 1999, 59, 1758-1775.

86 S. Grimme, J. Antony, S. Ehrlich and H. Krieg, J. Chem. Phys., 2010, 132, 154104-154123.

87 S. Grimme, S. Ehrlich and L. Goerigk, J. Comput. Chem., 2011, 32, 1456-1465.

88 Materials Studio v. 5.5, Accelrys Software, Inc.: San Diego CA, 2010.

89 J. M. Martínez and L. Martínez, J. Comput. Chem., 2003, 24, 819-825.

90 L. Martínez, R. Andrade, E. G. Birgin and J. M. Martínez, J. Comput. Chem., 2009, 30, $2157-2164$.

91 M. Digne, P. Sautet, P. Raybaud, P. Euzen and H. Toulhoat, J. Catal., 2002, 211, 1-5.

92 F. Weigend and R. Ahlrichs, Phys. Chem. Chem. Phys., 2005, 7, 3297.

93 M. J. Frisch, G. W. Trucks, H. B. Schlegel, G. E. Scuseria, M. A. Robb, J. R. Cheeseman, G. Scalmani, V. Barone, B. Mennucci, G. A. Petersson, H. Nakatsuji, M. Caricato, X. Li, H. P. Hratchian, A. F. Izmaylov, J. Bloino, G. Zheng, J. L. Sonnenberg, M. Hada, M. Ehara, K. Toyota, 
R. Fukuda, J. Hasegawa, M. Ishida, T. Nakajima, Y. Honda, O. Kitao, H. Nakai, T. Vreven, J. A. J. Montgomery, J. E. Peralta, F. Ogliaro, M. Bearpark, J. J. Heyd, E. Brothers, K. N. Kudin, V. N. Staroverov, R. Kobayashi, J. Normand, K. Raghavachari, A. Rendell, J. C. Burant, S. S. Iyengar, J. Tomasi, M. Cossi, N. Rega, J. M. Millam, M. Klene, J. E. Knox, J. B. Cross, V. Bakken, C. Adamo, J. Jaramillo, R. Gomperts, R. E. Stratmann, O. Yazyev, A. J. Austin, R. Cammi, C. Pomelli, J. W. Ochterski, R. L. Martin, K. Morokuma, V. G. Zakrzewski, G. A. Voth, P. Salvador, J. J. Dannenberg, S. Dapprich, A. D. Daniels, Ö. Farkas, J. B. Foresman, J. V. Ortiz, J. Cioslowski and D. J. Fox, Gaussian 09, Rev. D.01, Gaussian, Inc., Wallingford CT, 2009.

94 J. Vandevondele, M. Krack, F. Mohamed, M. Parrinello, T. Chassaing and J. Hutter, Comput. Phys. Commun., 2005, 167, 103-128.

95 S. Goedecker, M. Teter and J. Hutter, Phys. Rev. B, 1996, 54, 1703-1710.

96 C. Hartwigsen, S. Goedecker and J. Hutter, Phys. Rev. B, 1998, 58, 3641-3662.

97 X. S. Zhao, G. Q. (Max) Lu and G. J. Millar, Ind. Eng. Chem. Res., 1996, 35, 2075-2090.

98 S. Hitz and R. Prins, J. Catal., 1997, 168, 194-206.

99 R. A. A. Melo, M. V Giotto, J. Rocha and E. A. Urquieta-González, Mater. Res., 1999, 2, $173-179$.

100 D. Kumar, K. Schumacher, C. Du Fresne von Hohenesche, M. Grün and K. K. Unger, Colloids Surfaces A, 2001, 187-188, 109-116.

101 P. Michorczyk, J. Ogonowski, P. Kuśtrowski and L. Chmielarz, Appl. Catal. A Gen., 2008, 349, 6269.

102 A. Trouvé, I. Batonneau-Gener, S. Valange, M. Bonne and S. Mignard, J. Hazard. Mater., 2012, 201-202, 107-114.

103 B. Nanda, A. C. Pradhan and K. M. Parida, Micropor. Mesopor. Mater., 2016, 226, $229-242$.

104 P.-A. Albouy and A. Ayral, Chem. Mater., 2002, 14, 3391-3397.

105 W. Haynes, CRC Handbook of Chemistry and Physics, CRC Press, 2014.

106 M. Pfeiffer-Laplaud, D. Costa, F. Tielens, M. P. Gaigeot and M. Sulpizi, J. Phys. Chem. C, 2015, 119, 27354-27362.

107 R. L. Mozzi and B. E. Warren, J. Appl. Crystallogr., 1969, 2, 164-172.

108 C. Pophal, R. Schnell and H. Fuess, Stud. Surf. Sci. Catal., 1997, 105, 101-108.

109 C. Pophal and H. Fuess, Micropor. Mesopor. Mater., 1999, 33, 241-247.

110 M. Ookawa, K. Kawamura and T. Yamaguchi, Stud. Surf. Sci. Catal., 2004, 154, 1478-1484.

111 L. T. Zhuravlev, Colloids Surfaces A, 1993, 74, 71-90.

112 X. S. Zhao, G. Q. Lu, A. K. Whittaker, G. J. Millar and H. Y. Zhu, J. Phys. Chem. B, 1997, 101, $6525-6531$.

113 A. Guyot, G. E. Curtis and W. Libbey, Smithsonian Meteorological Tables: Based on Guyot's 
Meteorological and Physical Tables, 1896.

114 V. Kocherbitov and V. Alfredsson, J. Phys. Chem. C, 2007, 111, 12906-12913.

115 S. Ek, A. Root, M. Peussa and L. Niinistö, Thermochim. Acta, 2001, 379, 201-212.

116 A. K. Soper, J. Phys. Condens. Matter Phys. Condens., 2012, 24, 064107.

117 Á. Cimas, F. Tielens, M. Sulpizi, M.-P. Gaigeot and D. Costa, J. Phys.: Condens. Matter, 2014, 26, 244106.

118 D. Brunel, A. Cauvel, F. Di Renzo, F. Fajula, B. Fubini, B. Onida and E. Garrone, New J. Chem., 2000, 24, 807-813.

119 A. Jentys, N. H. Pham and H. Vinek, J. Chem. Soc. Faraday Trans., 1996, 92, 3287.

120 S. I. Karpov, F. Roessner and V. F. Selemenev, J. Porous Mater., 2014, 21, 449-457.

\section{TOC Figure}

\section{Hydration of MCM-41}

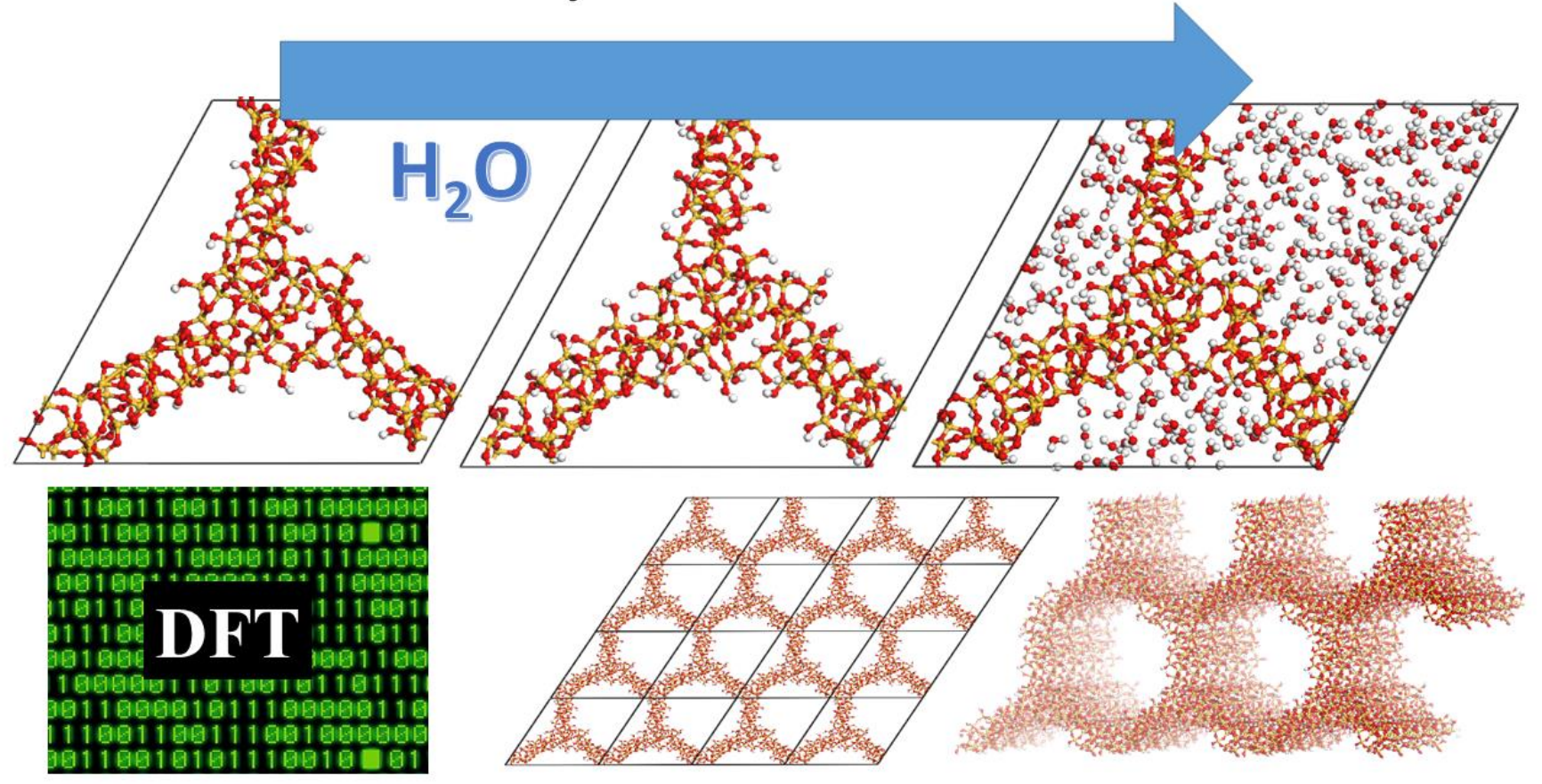

